\title{
Whose Science Wins or Loses? (And What's Left for Reason After?)
}

\author{
Hansun Hsiung, Durham University
}

$\mathrm{T}$ wo recent events bookend my reflections on what is living and what is dead in John Burnham's How Superstition Won and Science Lost. The first, held in over a hundred cities around the world on 4 May 2019, is the third iteration of the March for Science. From New York to Xiamen, Buenos Aires to Hyderabad, what could attest more dramatically to the extended global urgency of Burnham's diagnoses? Had it not already been clear, in 1987, that science-as a process of reasoning empirically and naturalistically - had failed to take hold in societies as a common "way of life," then it is certainly all too evident in our "post-truth" age of alternative facts and climate change denial. ${ }^{1}$ The March for Science can be seen as a worldwide regeneration of the moral imperative that drove Burnham's ideal of popularization, wherein civically oriented "men of science," filled with "evangelical fervor," sought to disseminate not only the products of their research but also the tools that would render each individual capable to make her own reasoned judgments (pp. 23-27, 247-252).

The second event weighing on my thoughts brings us to one of the principal sites of my own research: Japan. On 24 April 2019 the Japanese Parliament passed a bill to compensate those remaining survivors - an estimated twenty-five thousand persons - who had been forcibly sterilized under its Eugenic Protection Law, abolished only in 1996. ${ }^{2}$ If the March for Science ignites our evangelical fervor, then the legacy of the Eugenic Protection Law introduces challenges to it. As Michael Gordin underscores in his contribution to this Second Look section, the omission of eugenics from How Superstition Won was, however startling, deliberate. Eugenics campaigns often exemplified precisely those traits that Burnham praised as effectively combating superstition. Practicing scientists from Francis Galton to Alfred Ploetz, motivated by a strong ideal of the public good, presented systematic reasoning in lecture halls and learned journals that had yet to be fully conquered by advertising and consumerism. These campaigns, mobilizing conservatives and radicals alike, arguably represented some of the most "successful"

\footnotetext{
Hansun Hsiung works at the intersection of global history, the history of science, and media history. His book manuscript "Learn Anything! Cheap Print and the Education of the Modern World," under review at Princeton University Press, examines the communication infrastructures that shaped the transit of knowledge between East Asia and Western Europe, circa 1750-1900. His new project, "From Electrotype to the Electric Image: The Dawn of Global Vision," unearths the prehistory of the unification and control of graphic content at a distance, through an examination of early image banks and picture telegraphy in the nineteenth century. School of Modern Languages and Cultures, Durham University, Elvet Riverside, New Elvet, Durham DH1 3JT, United Kingdom; hansun.hsiung@durham.ac.uk.

Acknowledgments. My thanks to Alexandra Hui, Matt Lavine, Michael Gordin, Eric Gurevitch, and the anonymous referee for their illuminating input in shaping this piece.

${ }^{1}$ John C. Burnham, How Superstition Won and Science Lost: Popularizing Science and Health in the United States (New Brunswick, N.J.: Rutgers Univ. Press, 1987), pp. 13-16, 170. All subsequent references to this work are indicated in the text by page numbers.

${ }^{2}$ Motoko Rich and Makiko Inoue, "Japan to Compensate Forcibly Sterilized Patients, Decades after the Fact," New York Times, 25 Apr. 2019, https:/www.nytimes.com/2019/04/25/world/asia/japan-sterilization-eugenics-compensation.html.
} 
instances of scientific popularization in their time. ${ }^{3}$ Moreover, it was the popular force of eugenics during the American Progressive Era - an era depicted by Burnham as the final glory years of scientific popularization - that paved the way for its globalization to Japan. Rising at the end of the 1910s on the back of translations of Charles Davenport, Japanese eugenics was depicted simultaneously as an effort to "catch up" with the recent vanguard of Western science and as a confrontation with Western racial hierarchies. Thus reinterpreted as a core battlefield of modernity, eugenics thrived in Japan from the 1920s, even as many of the American geneticists whose writings played a formative role in its importation had begun to take a more cautious stance toward racialized eugenics. ${ }^{4}$

These two events of mid-spring 2019 together confront us with the need to rewrite the history of popularization for an age where science is global - and globally under siege. Bracketing the thorny issue of whether "science" and "superstition" can really be so neatly demarcated, this rewriting could begin with an attempt to reconcile the question of science's popular victories and losses with the question of whose science wins or loses - and thus who wins or loses - whenever we popularize a thing we claim to be "science." A producer-centric account, How Superstition Won largely ignores these latter problems, gesturing instead to an abstract American "people." Yet as critics of the term "popular" and "popularization" have argued, the specific circulatory infrastructures in which communicative acts are embedded produce shifting configurations of audiences, the makeup of which fits uneasily into established social categories, such as class, ethnicity, gender, and nationality. ${ }^{5}$ We therefore need to examine how historical infrastructures of communication, in creating different and uneven conditions of circulation, created different and uneven "peoples" - different and uneven subjects and subject positions in relation to "science."

Were we to apply this method to the nineteenth century - for Burnham, the century of popularization's genesis and zenith - then the following becomes clear: scientific popularization was always about a global "people." This is not to say that popularization and globalization were the same. But within the context of the nineteenth century's radical geopolitical asymmetries, popularization and globalization were necessarily entangled: "Never had European culture been so eagerly soaked up by others," writes Jürgen Osterhammel, "far beyond the sphere of colonial rule." Popularizers themselves, as well as those who read their works, had long recognized this entanglement. After the Society for the Diffusion of Useful Knowledge (SDUK) launched in 1826, its General Committee, in conjunction with the publisher Charles Knight, immediately began "institut[ing] inquiries as to the best mode of supplying the Indian market" and within the next decade had provided financial support, printed matter, and stereotyped plates of illustrations for initiatives in India, Singapore, Canton, Guatemala, and the West

\footnotetext{
${ }^{3}$ Daniel J. Kevles, In the Name of Eugenics: Genetics and the Uses of Human Heredity (New York: Knopf, 1985); and Frank Dikötter, Imperfect Conceptions: Medical Knowledge, Birth Defects, and Eugenics in China (New York: Columbia Univ. Press, 1998). On the cooptation of radical labor and feminism by eugenics see Nick Hopwood, "Producing a Socialist Popular Science in the Weimar Republic," History Workshop Journal, 1996, 41:117-153; Sumiko Otsubo, "Engendering Eugenics: Feminists and Marriage Restriction Legislation in the 1920s," in Gendering Modern Japanese History, ed. Barbara Molony and Kathleen Uno (Cambridge, Mass.: Harvard Univ. Asia Center, 2008), pp. 225-256; Ann Taylor Allen, "German Radical Feminism and Eugenics, 1900-1908," German Studies Review, 1998, 11:31-56; and Angelique Richardson, Love and Eugenics in the Late Nineteenth Century: Rational Reproduction and the New Woman (Oxford: Oxford Univ. Press, 2008).

${ }^{4}$ Sumiko Otsubo and James Bartholomew, "Eugenics in Japan: Some Ironies of Modernity, 1883-1945," Science in Context, 1998, 11(3-4):545-565; Kevles, In the Name of Eugenics, pp. 148-175; and Kenneth M. Ludmerer, "American Geneticists and the Eugenics Movement: 1905-1935," Journal of the History of Biology, 1969, 2:337-362.

${ }^{5}$ Roger Chartier, The Order of Books: Readers, Authors, and Libraries in Europe between the Fourteenth and Eighteenth Centuries, trans. Lydia G. Cochrane (Stanford, Calif.: Stanford Univ. Press, 1994), pp. 6-8.

${ }^{6}$ Jürgen Osterhammel, The Transformation of the World: A Global History of the Nineteenth Century, trans. Patrick Camiller (Princeton, N.J.: Princeton Univ. Press, 2014), p. xx.
} 
Indies. ${ }^{7}$ Readers of that "most valuable contribution to popular science," John Herschel's Outlines of Astronomy, remarked on how it was "admirably adapted for the instruction of a large class of Chinese" and "likely to be even more widely appreciated, for it has already been sought with avidity by the Japanese, and application has also been made for Cochin china [sic] by natives of that country." In short, global circulation was not incidental to, but an integral feature of, how the "people" of popularization were understood. ${ }^{\text {" }}$

Once we accept that popularization's "people" were more than national or regional, our portrait of its social dynamic also necessarily changes. In particular, we observe a dynamic of audience "upcycling," wherein the "popular" at home created new elites abroad. ${ }^{10}$ Here, the example of Japan is instructive. The infrastructures of long-distance communication in the mid-nineteenth century imposed political, economic, and intellectual limitations on Japanese access to foreign knowledge. Suspicion of Christianity meant both that contact with Protestant missionaries, key agents of the global circulation of science, was restricted to an approved class of scholars and that the texts these missionaries brought with them - those of Augustus De Morgan and John Herschel, for example - fell under close government control. ${ }^{11}$ When approved for circulation, foreign texts still often proved prohibitively expensive: issues of Dutch penny magazines, for instance, were valuable enough to function as whole dowries among families of samurai status in the $1850 \mathrm{~s} .{ }^{12}$ This is not to mention intellectual barriers. First, the continued centrality of mastery of the classical Chinese corpus meant that dominant scholarly elites were ill equipped and ill motivated to deal with new works in European languages. As a result, the reading and translation of these latter texts fell on the shoulders of second or third sons of samurai families who were not the principal inheritors of property and titles and thus were less constrained to acquire the trappings of traditional legitimacy. Second, the new concepts and terms contained within these works meant that even in translation "popular" scientific texts were notoriously difficult to understand, featuring a host of competing and unstandardized neologisms legible to but a few. ${ }^{13}$ Scientific knowledge capital therefore came to be consolidated in the hands of what could be called subdominant elites. After the Meiji Restoration of 1868 abolished traditional status groups, these

\footnotetext{
${ }^{7}$ Charles Knight to the SDUK, April 1829, in Letters, Box 23; Minutes, Vol. 2, Committee Papers, Box 2; J. F. Davis to the SDUK, 4 Dec. 1833, in Letters, Box 25; and Antigua Union Society to the SDUK, 19 Dec. 1838, in Letters, Box 20: Society for the Diffusion of Useful Knowledge Papers, UCL Special Collections, London.

${ }^{8}$ Alexander Wylie to John Herschel, 21 Nov. 1860, HS 19.303, Herschel Papers, Royal Society, London.

${ }^{9}$ Stressing the "global," in distinction to the "colonial," as integral rather than incidental to popularization helps address Andreas Daum's call for popularization histories that "break out of the boundaries of nation-states as seemingly coherent entities and overcome hierarchies based on a dichotomy between (imperial) centers and (colonial) peripheries": Andreas W. Daum, "Varieties of Popular Science and the Transformation of Public Knowledge: Some Historical Reflections," Isis, 2009, 100:319-332, on pp. 324-325. For an attempt to distinguish between the textbook as a "colonial" versus "global" genre see Hansun Hsiung, "The Circle of Knowledge: Radical Commensurability and the Deaf Textbook," in The Global Histories of Books: Methodologies and Practices, ed. Elleke Boehmer et al. (Cham: Palgrave Macmillan, 2017), pp. 161-187.

${ }^{10}$ In its original usage, the term "upcycling" referred to the recycling of textual matter into a higher-prestige publication format; here, I use it to refer to the same textual matter finding itself in the hands of audiences of a higher social status than the one originally intended. See Antoinette Burton and Isabel Hofmeyr, "Introduction: The Spine of Empire? Books and the Making of an Imperial Commons," in Ten Books That Shaped the British Empire: Creating an Imperial Commons, ed. Burton and Hofmeyr (Durham, N.C.: Duke Univ. Press, 2014), pp. 1-28, esp. p. 2.

${ }^{11}$ See, e.g., the partial transcription of the censorship ledger of the Institute for the Investigation of Barbarian Books (Bansho shirabesho), Kaihan miaratame genchō, in Nihon kagakushi gakkai, ed., Nihon kagaku gijutsu-shi taikei, Vol. 1 (Tokyo: Daiichi Hōki Shuppan, 1964), pp. 61-66.

${ }^{12}$ Yanagida Izumi, "Koga Chakei-cho Donichi kangen saishū kōgi," Waseda Daigaku shi kiyō, 1965, 1(1):213-221, esp. p. 215.

${ }^{13}$ Indeed, some claimed that many translations could not be understood without a prior knowledge of the original text. See Tōkyō shoseki shuppan eigyō-sha kumiai, Bankoku hanken hogo dōmei jōyaku kanyū ni kan suru ikensho (1897), in Shinbunshi shiryō shūsei, Vol. 10 (Tokyo: Yumani shobō, 1995), pp. 221-226.
} 
subdominant elites emerged as dominant, constituting the new class in charge of spearheading modernization reforms.

As upcycling shows, the distinction between a "popular" and an "elite" text fluctuates relative to infrastructures of communication. ${ }^{14}$ More important, it shows that categories such as Burnham's "lower orders" (pp. 32-33) of society fail to capture a broader dynamic wherein popularization produced profound social rearrangements. To put it programmatically, we must be attentive to how each configuration of a "people" in need of science, once situated in different infrastructures of communication, reinforces or upsets existing configurations of political participation. ${ }^{15}$ Popularization involves the constant redrawing of boundaries of inclusion and exclusion, internal structures of domination and subordination, and norms that actors must obey to make their speech heard. These boundaries, structures, and norms may, but do not necessarily, correspond to those hegemonic in a given society, meaning that popularization should never assume a top-down model in relation to the overall social structure but should focus as well on lateral rearrangements and the elevation of subordinated counterpublics to the status of dominant publics. ${ }^{16}$

These observations mark a start to answering the question of who and whose science wins or loses. They compel us to examine popularization as a phenomenon constituted mutually by "peoples" at home and abroad, whose always impure and composite makeups actualize unique fault lines and fragmentations - but also hidden opportunities for the seizure of sociopolitical power.

Unanswered, however, remains the core question of Burnham's book: the victory and loss of superstition or science overall. True enough, we may find it difficult today to accept Burnham's portrayal of science as the standard of all that is enlightened and rational. Nevertheless, the spirit that animates his inquiry has not lost its imperative. For behind How Superstition Won's popularization of science is, more fundamentally, the problem of popular reason. It is a problem of how reason can be made a common "way of life" for all and what infrastructures of communication might guarantee this.

In this sense, Burnham stands aligned, perhaps unexpectedly, with Jürgen Habermas, whose analysis of the conditions for a critical-reasoning public sphere similarly prioritized institutions of communication and similarly expressed much invective against twentieth-century mass media, advertising, and consumer culture. ${ }^{17}$ And this analogy is worth preserving, for it reminds us that the particular study of the social circulation of ideas that we call "popularization" is in fact central to the project of communicative reason itself.

To point out that different "peoples" always win or lose in popularization is not to act as a "defector," in Burnham's terms (pp. 259-262), from this project. Rather, it is to demand that

\footnotetext{
${ }^{14}$ For a thoughtful problematization of categories of high/low and elite/popular based on the empirical study of readership see Jonathan Rose, "Rereading the English Common Reader: A Preface to a History of Audiences," Journal of the History of Ideas, $1992,53: 47-70$.

${ }^{15}$ This links the history of scientific popularization with resurgent interest in political theory concerning how acts that seek to define "the people" constitute the core battleground of "the political." See Jan-Werner Müller, What Is Populism? (Philadelphia: Univ. Pennsylvania Press, 2016).

${ }^{16}$ I borrow the term "counterpublics" from Nancy Fraser, who uses it to challenge the notion of a "single, comprehensive, overarching public" and to highlight alternative spaces "where members of subordinated social groups invent and circulate counterdiscourses to formulate oppositional interpretations of their identities, interests, and needs": Nancy Fraser, "Rethinking the Public Sphere: A Contribution to the Critique of Actually Existing Democracy," in Habermas and the Public Sphere, ed. Craig Calhoun (Cambridge, Mass.: MIT Press, 1992), pp. 109-142, on pp. 122-123. See also Michael Warner, "Publics and Counterpublics," in Publics and Counterpublics (New York: Zone, 2002), pp. 65-124.

${ }^{17}$ Jürgen Habermas, The Structural Transformation of the Public Sphere: An Inquiry into a Category of Bourgeois Society, trans. Thomas Burger and Frederick Lawrence (Cambridge, Mass.: MIT Press, 1989), pp. 181-196. For Burnham's take on mass media see Burnham, How Superstition Won and Science Lost (cit. n. 1), pp. 74-81, 229-247.
} 
the "reason" this project fosters be open-ended-embracing, if not a metaphysical, then at least a pragmatic pluralism wherein certain epistemic claims can be acknowledged as preferable to others, without denying the potential value of these other claims in revealing new or forgotten ways of thinking that could yield vital contributions to science in the future. ${ }^{18}$ Communicative reason, in this sense, would be understood as an active and constant dialogue with difference. A history of popularization that took this orientation as its premise would then seek less to document any one version of science's victory or loss, as Burnham did, and more to examine which infrastructures of communication promoted the sustained coexistence of multiple epistemic claims within a broad public arena. When more and different configurations of "people" can participate, when new and different "peoples" can be seen and heard-this is the form of popularization through which science wins.

\footnotetext{
${ }^{18}$ Although he would likely object to the modifier "pragmatic," the pluralism I invoke here is meant to echo Hasok Chang's account of "active normative epistemic pluralism." See Hasok Chang, Is Water $\mathrm{H}_{2} \mathrm{O}$ ? Evidence, Realism, and Pluralism (Dordrecht: Springer, 2012), pp. 253-301.
} 